\title{
MYTH-AND-SYMBOLIC MODIFICATION \\ OF THE ART WORLD BY MEANS OF PHYTOSYMBOLISM IN THE WORKS OF JEAN GENET'S “NOVELISTIC” PERIOD
}

\section{Semenets O. S.}

\section{INTRODUCTION}

The poetics of the writer's works which are part of his genre chosen combines the poetic means of autobiography with a specific author's style, marked by the tendency to bright floral symbolism and colorful palette. According to V. Colonna such a rich symbolism of Jean Genet 's prose with its emphasis on floristics is the feature that prevents us from positioning his prose as an example of an "autobiographical novel”.

Describing J. Genet's work as the subject, problematic and poetic matter Y. Pokalchuk deduces the writer`s "formula of popularity": he rhythmizes the classic prose style, expresses it in the argo language and indecent descriptions of erotic relations especially between men. In this way J. Genet, according to Y. Pokalchuk, "looks out of the public hell into the Lost Paradise of human beauty and sincere feelings, poetizing Montmartre prostitutes and petty thieves, murderers and traitors, inmates of the lower world, the lower layers of society, guys for whom love between men is a natural phenomenon"1. In this way "discovering the beauty", he "discovered poetry". The writer repeatedly emphasized that he wrote not prose but poetry. And although he sometimes strived for "dry and even bony style", he still appealed to us "from the depths of his prison" by a book "un livre chargé de fleurs, de jupons neigeux, de rubans bleus"2.

As to using artistic means, Genet's language tends to be more poetic. He does not aim to recreate his life, but rather to convey emotions, aesthetically affecting the reader. In an attempt to describe the most disgusting things for the average reader in the most wonderful words, to accompany the mention of pus, faeces, vomiting by the most poetic epithets, a marginal mentality of Genet manifests. The process of overcoming the inner splitting is realized in the adaptation of eternal

\footnotetext{
${ }^{1}$ Покальчук Ю. Дзеркальні лабіринти «святого» Жене / Ю. Покальчук // Покоївки : [П'єса] / Жан Жене ; [пер. із фр. та післямова Ю. Покальчука]. - Львів : Кальварія, 2002. - С. 89.

${ }^{2}$ Genet J. Notre-Dame des Fleurs / Jean Genet. - Lyon: Barbezat-L'Arbalète, 1948. P. 204.
} 
cultural symbols to the marginalized society described, because he saw no other beauty.

Writing for Genet means "Poussé par un seul mobile - esthétique $<\ldots>-$ avant que d'écrire entrer dans la possession de cet état de grâce qui est une sorte de légèreté, d'inhadérence au sol, au solide, à ce qu'on nomme habituellement le réel $<\ldots>$ ". 3 . The writer distinguishes himself from the novelist who is free from " $<\ldots .>$ aborder n'importe quel sujet, parler de n'importe quel personnage avec toujours une précision rigoureuse $<\ldots>$ " 4 , and approaches himself to the poet " $<\ldots>$ est soumis aux exigences de son coeur qui attire à lui tous les êtres marqués à l'angle par le malheur <...>5. Genet's art is focused on the topic of death, because being a poet he was always interested in such matters and, therefore, engaged in evil. His role is to show us the beauty that is embodied in evil, to get it from there and to use it with benefit.

For Friedrich von Schlegel poetic creativity is an "eternal symbolization". Poetry in Genet's prose is also full of symbols, ranging from the archaic to the Christian, it could be no other way as he could only use the "mystical language of all religions" to glorify his Gods. Cultural symbols actively correlating with the cultural context (in this case functioning in the opposite to the generally accepted norms of the world of artistic space), are transformed under its influence and transform it themselves. Genet explains the use of cultural symbols transposed into the plane of marginality in the following way: "C'est $d u$ plus profond de moi que je les arrache, d'une région où l'ironie n'a pas accès et ces mots, chargés de tous les désirs que je porte enfouis, les exprimant, au fur et à mesure que je les écrirai, sur le papier, referont le monde détestable et adoré <... "6. It was Y. Lotman who noted that "the symbol exists outside of this text and independently of it. It falls into the writer's memory from the depths of cultural memory and comes to life in new text like grain that has fallen into new ground"7.

In Genet's autofictional prose certain symbolism is present in every comparison, metaphor, parallel, even in the epithet. Using the multilayered semantic structure of the symbols used, Genet tries to bridge the gulf between the essence and the visibility of the depicted world,

\footnotetext{
${ }^{3}$ Genet J. Pompes Funèbres / Jean Genet. Paris, Gallimard, 1953. P. 271-272.

${ }^{4}$ Ibid. P. 103.

${ }^{5}$ Ibid. P. 104.

${ }^{6}$ Genet J. Miracle de la rose // Oeuvres completes de Jean Genet / Jean Genet. II. Paris, Gallimard, 1952. P. 36.

7 Лотман Ю. М. Символ в системе культуры / Ю. М. Лотман // Избранные статьи. В 3-х т. Таллинн : Александра, 1992-1993. Т. 1. : «Статьи по семиотике и типологии культуры». 1992. С. 192.
} 
between the conventional and the personal, and thus symbolically opposes social alienation, although never overcoming it. Using Christian symbols to identify and characterize murderers and prostitutes, traitors and venal people the writer tries to bring to the reader as a representative of moral society, his own ethical-aesthetic concept which underlies the primal desire for holiness.

Certain aspects of floral symbolism used in the works of Jean Genet were analyzed by P.-M. Eron, V. Colonna, J. P. Sartre and N. Fredett. In particular, in "Saint Genet, an Actor and a Victim" J. Sartre (Sartre J.-P. "Saint Genet, comedien et martyr") examines floristry in the focus of the concept of holiness. N. Fredett (Fredette N. Figures du baroque de Jean Genet) in his book "Baroque Figures" analyzes it in terms of stylistic use. V. Colonna (Colonna V. L'Autofiction (Essai sur la fictionnalisation de soi en littérature)) addresses to the issue of widespread use of floral symbolism in the aspect of the poetics of autofiction. As to us we will focus on the functional purpose of this poetic dominance in the writer's works as the means of achieving the author's primary purpose - to portray the world of thieves, invaders and prostitutes according to the laws of beauty.

\section{Functions of floral symbolism in the Jean Genet's novel "Our Lady of the Flowers"}

The Mettray Penal Colony penitentiary where Jean had spent his youth, was located in a picturesque place. Its yards and surroundings were full of flowers, bushes, trees. Love to nature and its perfection, sense of unity, understanding of its cyclical essence contributed to the fact that becoming a writer aiming to magnify the beauty, even the beauty of the disgusting things, he turned to images and symbols of nature. Mentioning Meter Jean writes: "La Colonie menait là, parmi les fleurs (qui, depuis elle, me sont accessoires infernaux, ces fleurs de jardin et celles que j'offre aux soldats morts, inquiet qu'elles ne suffisent), et des arbres d'essences rares, sa vie secrète $<\ldots{ }^{\text {" }}$. Combining in symbols of nature such opposing concepts as life and death, death and revival, happiness and grief, good and evil, his system of floristic symbolism of novels is based. Using them the author embodies his original, mysterious vision of the world and life.

${ }^{8}$ Genet J. Miracle de la rose // Oeuvres completes de Jean Genet / Jean Genet. II. Paris, Gallimard, 1952, P. 15. 
The importance of the theme of God and the symbols of nature for $\mathrm{J}$. Genet is already indicated by the titles of his first novels "Our Lady of the Flowers" and "Miracle of the Rose". They accumulate the basic idea of the works. By the way, in these novels the leading role is given to floral symbolism, while in other prose works the meaning is transferred to the symbol of the tree.

So the novel "Our Lady of the Flowers" was named after one of the main characters - a thief, a prostitute and a murderer. This proves the author's desire to "purify" it, because the image of "flower" is a symbol of innocence, kindness, the joy of paradise: "Mais vint Notre-Dame-desFleurs, qui avait un caractère physique et moral de fleur, elle s'en amouracha"9. A flower is a symbol of covenant - birth, life, death and rebirth. At the end of the novel it becomes known that this is the path of life that the hero is destined to experience.

Generalized image of a flower (without its specific definition) is most common in the novel. Most of these unspecified characters are met at the beginning of the novel. In the second part of it specific flowers and other plants are already mentioned - cypress, orange blossom, ivy, etc. Symbols of some flowers are mentioned throughout the whole novel (rose, lily, mimosa). In our opinion, this feature is due to the fact that different types of flowers have different symbolic content, which depends on the shape, color and number of petals. The unspecified flower mostly symbolizes the feminine origin, the passive principle which leading role is assigned in the novel. It is a symbol of flourishing of spiritual life in many religions (for example, Buddha and Brahma are depicted among the flowers). Genet compares Minignon with the god baptized in the womb which " $<\ldots>$ construit pour cette vie de mac un piédestal enguirlandé des fleurs $<\ldots>$ ". 10 . In Buddhism flowers symbolize the transitional state of the body that is why they are used during worship. For Genet flowers are always presented near the corpses: "Il avait tué sa femme, puis, l'ayant assise sur un coussin de soie jeune à petits bouquets verts, il l'avait murée, en donnant à la maçonnerie la forme d'un banc"11. The character seemed to represent a murder as a sacred ritual. As after committing a crime, a person goes to the other side, the laws of the ordinary world lose their power over that person. This moment of transition is depicted by Genet as a ritual of initiation into the mystery of death.

\footnotetext{
${ }^{9}$ Genet J. Notre-Dame des Fleurs / Jean Genet. Lyon: Barbezat-L'Arbalète, 1948. P. 50.

${ }^{10}$ Ibid.

${ }^{11}$ Ibid. P. 176.
} 
Divine's mother, Ernestine, dreamed to kill herself and die among gardening and flowers. Because the Virgin Mary is often portrayed with a flower in her hands, Jean Genet's characters - drag queens Divine, Mimosa, Dede and others - often hold flowers in their hands: "Tandis que dans la rue, sous l'auréole noire des parapluies minuscules et plats qu'elles tiennent d'une main comme des bouquets, Mimosa I, Mimosa II, Mimosa mi-IV, Première Communion, Angela <... ${ }^{\prime 12}$.

Flower as a symbol of beauty, natural innocence, divine blessing, the joy were used by Divine in the following way: "<..> passé des fleurs aux boutonnières de la braguette" une fleur de velours dans ses cheveux ébouriffés"14 thus accompanying the ritual of reincarnation of the latter into a woman.

Genet endows "ordinary people" with the attributes of artificial flowers, as symbols of the falsehood that they accept for happiness which does not correspond to the true ideals: " <...> processions composées de fillettes aux têtes de porcelaine, vêtues de robes blanches et couronnées de fleurs d'étoffe <...>"15, or "Les murs éblouissant de lumières et de glaces, capitonnes, ornes de fleurs d'étoffe dans des vases en verre, et de gravures galantes"16. In the same way the author compares his characters, forced to stand trial under real male names, to "<...> la fleur de papier que tient le danseur au bout de ses doigts et qui n'est plus, le ballet fini, qu'une tige de fer"17. The pseudowomen loose their holy halo that surrounded them throughout their life at the bottom of society.

In addition to Notre Dame, the novel features another floral character - Mimosa the First, the main homosexual prostitute which gave names to a number of her successors and girlfriends (Mimosa the Second, Mimosa the Third, Mimosa the Half-Four). The mimosa flower was revered by many religions, symbolizing confidence in rebirth and spiritual renewal (it was considered by Egyptians to be the first plant to believe in Christ). By choosing such a name for the character, Genet seems to purify her from the filth of public prejudice, giving a divine spirit to her body. It is no coincidence that Mimosa the First appears in Divine's life in the moment when the latter begins to lose faith when she dies.

Another distinctive floral symbol of "Our Lady of the Flowers" is the lily. At the end of the story Genet compares her characters with lilies:

\footnotetext{
${ }^{12}$ Genet J. Notre-Dame des Fleurs / Jean Genet. Lyon: Barbezat-L'Arbalète, 1948. P. 50. P. 19.

13 Ibid. P. 89.

${ }^{14}$ Ibid. P. 250.

${ }^{15}$ Ibid. P. 142.

${ }^{16}$ Genet J. Querelle de Brest / Jean Genet. Paris, Gallimard, 1953. P. 29.

${ }^{17}$ Genet J. Notre-Dame des Fleurs / Jean Genet. Lyon: Barbezat-L'Arbalète, 1948. P. 339.
} 
"Comme des lis tout droits, surgissent des jeunes hommes, qui sont, un peu grâce à moi, princes et gueux à la fois"18. This suggests that the author compares himself to Mary-Eve, from whose tears the lilies (in the case of J. Genet - the characters of the novel) grew, when she left paradise. As Mary opened the way to the Lord for humans, so did Genet, showing the fate of his characters, showing the way to purification and holiness. He sais: "Les Grands macs inflexibles, stricts, sexes épanouis dont je ne sais plus s'ils sont des lis ou si lis sont sexes <... ${ }^{\text {"19. }}$. Preaching the divine nature of "pimps", Genet compares their genitals to the lily which has long been the embodiment of the cup in which the divine essence of life is preserved.

Violet is a symbol that runs through the whole novel (just like a lily and a mimosa) and is multifaceted. This flower is an attribute of the Divine and other prostitutes because it symbolizes humility (St. Bernard calls St. Mary the "violet of humility"), innocence and chastity. Perhaps this is a modern-day version of an ancient ritual during which children were handed bouquets of violets to show that they were already young citizens. So is Genet trying to prove us that even those who are not considered human beings have the right to vote. Violet flowers in "Our Lady of the Flowers" are also found when it comes to the funeral ceremony, as they are symbols of sadness, sorrow and death. And Greeks decorated the deathbed of the prematurely killed and the graves of young girls: "Le tapis de velours noir de l'Hôtel Crillon où reposait le cercueil d'argent et d'ébène contenant le corps embaumé de la Princesse de Monaco était jonché de violettes de Parme" ${ }^{20}$ or " $<\ldots>$ la chambre de Bernadette Soubirous, à l'heure de sa mort, était pleine du parfum d'invisibles violettes" ${ }^{21}$.

Rose is another pivotal symbol of all Genet's work. In Christianity this flower is a symbol of mercy, forgiveness, charity, love, martyrdom and purity. Maybe that's why the storyteller chose it to attach to the attic door where Divine lived as a symbol of the heavenly reward for holiness. The heroine herself embarked on the path of the Virgin, to whom a rose was devoted long ago. This flower is also a symbol of mystery and silence. It was her clue to the policemen who came to Notre Dame with a routine search of the house where the murder was committed: "Les policiers flairaient le crime, <...>. Il y avait des roses sur la cheminée,

\footnotetext{
${ }^{18}$ Ibid. P. 306.

${ }^{19}$ Genet J. Notre-Dame des Fleurs / Jean Genet. Lyon: Barbezat-L'Arbalète, 1948. P. 13.

${ }^{20}$ Ibid. P. 19.

${ }^{21}$ Ibid. P. 155.
} 
en face d'eux" ${ }^{22}$. They did not find the drugs they were looking for, but came across a mangled doll dummy and they hadn't left: "Les roses de la cheminée étaient belles, lourdes et excessivement parfumées. Les policiers n'en étaient que moins d'aplomb"23. The flowers seemed to indicate that there was a secret here, and their suspicions had come true. After a while, Notre Dame confessed to the murder and accepted his fate. Thus, the rose had played a decisive role in the self-awareness of the murderer as a man of choice, consecrated through the murder, of a burning man.

It is the withered roses symbolizing the transience of earthly goods and the emblem of the shadow realm, that pointed to premature death of Notre Dame: "Les roses de ses cheveux étaient en étoffe : malgré cela, elles s'étaient fanées sur le laiton, mais elles tenaient bon encore $<\ldots>$ ". 24, "Les roses d'étoffe étaient bien mortes"25. Deliberately not indicating the color of the rose, although colours played a significant role in all the works of Genet, the writer emphasizes the ambivalence of this symbol (it is simultaneously heavenly perfection and earthly passion, time and eternity, life and death, fertility and chastity), which showed themselves in the characters. Only once the author mentioned the story of Anna Boleyn's execution and an image of a bush of white roses appeared in his imagination: " $<\ldots .>d u$ sang fumant, jaillit un buisson de roses, peut-être blanches, mais sûrement parfumées)" "26. Genet tries to decorate Anna's death, consecrate it, as according to the legend the roses grew where the drops of St. Francis blood fell on the ground, and the white color of the flower symbolizes purity, virtue, chastity, love of God.

When the imprisoned narrator peeked at his naked cellmate killer which later became his lover, he compared his feelings to a "rose petal shower". The large number of petals in Christianity symbolizes the degree of consecration, and the water of roses was used during christening (Genet describes his own sanctification and insight in the prison where he approached God with every fail).

There are other flowers-symbols in the work, which are the decoration of actions and taboos for society. Describing one of her lovers, Gorgias, Divine recalls that "Un gros chrysenthème fanait à sa boutonnière" ${ }^{27}$. This flower is a symbol of dignity, courage, bravery and

\footnotetext{
${ }^{22}$ Ibid. P. 311.

${ }^{23}$ Genet J. Notre-Dame des Fleurs / Jean Genet. Lyon: Barbezat-L'Arbalète, 1948. P. 330.

${ }^{24}$ Ibid. P. 254.

${ }^{25}$ Ibid. P. 254.

${ }^{26}$ Ibid. P. 326.

${ }^{27}$ Ibid. P. 252.
} 
nobility. This was how the heroine felt about Gorgias at the beginning, but the fact that the chrysanthemum is fading seems to divine disappointment in the lover's virtues.

Divine " $<\ldots>$ se mêle davantage à la vie des tentes. Elle se multiplie dans les bars minuscules. Elle s'ébroue, s'ébouriffe, et croit, au milieu de tous nos gestes, jeter, les semant autour d'elle, des pétales de roses, de rhododendrons et de pivoines, $<\ldots>{ }^{* 28}$. Rose is a symbol of beauty, perfection, grace and happiness; rhododendron symbolizes soul renewal, hope, as well as a symbol of the goddess hunter that is self-defense and warning that no one is allowed to offend you. Peony is a symbol of tenderness, shyness, love, beauty, nobility of the soul. These virtues are cherished by the character and she tried to sow them around.

The carnation that appears only once in "Our Lady of the Flowers" during the first meeting of Divine and Mignon, is a symbol of the Christian understanding of love. It blossomed the very day Jesus was born. "Il m'apparut qu'il aurait pu avoir, couché nu dans un champ d'oeillets" 29 . On the one hand, carnation is a flower of struggle, of courage, and this was how Divine felt about her future lover. On the other hand, it has long been used in wedding ceremonies, symbolizing marital relations. And the field of carnations where she saw her lover became a harbinger of their relationship. But the "field" identified with insecurity, threat and perdition, predicted the fragility of this union.

Wheat and rye, which appear only in the Divine-Kulafrois's childhood episodes, are indicators of material and productive wealth, because it was his childhood when the character had a family, well-being and confidence. Cactus and magnolia are also symbols of childhood. Kulafroi imagines her childhood as a desert with cactuses - " $<\ldots$.. $>$ tout minuscule ou immens - on ne sait - abrité par la lumière, le parfume et le flux de charme personnel d'un gigantesque magnolia fleuri qui montait dans un ciel $<\ldots>$ ". 30 . This childhood period " $<\ldots>$ séchait sur son sable brûlé, avec un aperçu sur le magnolia invisible $<\ldots{ }^{\prime 31}$. A desert in Christian culture means the place of revelation; it is where the devil tempted Christ, where the prophets came from. Cactus symbolizes chastity; magnolia symbolizes honesty and purity. As a child, the character began to discover himself, to understand his essence, being

\footnotetext{
${ }^{28}$ Genet J. Notre-Dame des Fleurs / Jean Genet. Lyon: Barbezat-L'Arbalète, 1948. P. 227.

${ }^{29}$ Ibid. P. 21-22

${ }^{30}$ Ibid. P. 137.

${ }^{31}$ Ibid. P. 137.
} 
surrounded by cactuses as the charm of his virtue. Throughout his life he tried to maintain the purity and honesty, which were the main source of Divine's spirituality.

The list of floral symbols of the novel "Our Lady of the Flowers" is not decisive. Images of other flowers such as mignonette, ivy, frankincense, bindweed, wild rose, orange blossom and others play the role of attributes for certain events. For example, Genet used the symbol of forget-me-nots when describing the events that deeply rooted in the memory of the character.

\section{The Central Floral Symbols of the Novel "Miracle of the Rose"}

In the novel "Miracle of the Rose", along with the story of HHarcamonee and the Fontevrault prison and the childhood of Genet is depicted in Mettray Penal Colony, the narrator explains his attraction to the use of floral symbols: "La Colonie menait là, parmi les fleurs (qui, depuis elle, me sont accessoires infernaux, ces fleurs de jardin et celles que j'offre aux soldats morts, inquiet qu'elles ne suffisent), et des arbres d'essences rares, sa vie secrète $<\ldots>$ "32. Such combination of seemingly incompatible concepts as prison, which was "a real hell where unprecedented outrages were made" and flowers with trees that had the entire Great Courtyard of the colony bloomed, gave life to the image of Mettray Penal Colony in Genet's mind: “<...> étrange enfer où même le très particulier parfum de l'Enfer se manifestait sous les apparences ahurissantes d'un rosier chargé de roses soufre" "33. In his adulthood the narrator realizes that he was "paradoxically happy" in the penitentiary and that was the place which made him the one he is now, he recalls his numerous attempts to escape the walls of the hedgerow describing it: "Enfant, je m'enfuis à la course de Mettray. Je ne sais plus ce qui me commanda un après-midi de dimanche de rompre le cercle enchanté des fleurs, de lâcher mes sabots et de voler à travers la campagne. Passés les lauriers, le terrain était en pente. Je dévalai, comme on roule, les prés et les bosquets, instinctivement choisissant les limites des champs où, plus qu'ailleurs, ma silhouette avait des chances de se confondre"34. The laurel is a symbol of eternal life, purification, protection, divinity, secret knowledge, flowers are the symbols of youth, the field is the symbol of insecurity and hostility. While in prison where the truth was revealed to

${ }^{32}$ Genet J. Miracle de la rose // Oeuvres completes de Jean Genet / Jean Genet. II. Paris, Gallimard, 1952. P. 15.

${ }^{33}$ Ibid. P. 107.

${ }^{34}$ Ibid. P. 192. 
him, he felt protected, when leaving the prison, he went down his path, always choosing a liminal position, never completely breaking up with the free expanse of forests, representing the criminal world, and never stepping on unknown territory of the meadows. The narrator knew that someday he would have to leave Mettray Penal Colony: “<...> de rompre le barrage des fleurs, d'entrer dans le fabuleux en le combatant" 35 . Thus during his life, Genet had always been fascinated by the abrupt falling through prisons, impurity and hell to the most magical place in the world to "dans un jardin de sainteté où fleurissent des roses dont la beauté - je le saurai alors - est faite de l'ourlet des pétales, de leurs plis, de leurs déchirures, de leurs pointes, taches, trous d'insectes rougeurs et jusqu'aux tiges mousseuses à force d'épines" ${ }^{36}$, to Mettray Penal Colony, the best place in the world. Each colonist is a rose there, and their beauty lies in their shortcomings, in their disgusting appearance and blackened souli.

The attempt of the authorities to disguise the colony as a blossoming paradise, to put a fence of yew trees (guarding children from demonic powers), to flourish the court with hunger (hope), roses (mercy, mercy, forgiveness, martyrdom and forgiveness) and jasmine (worship, tender love) encouraged the narrator to believe in paradise on earth. He calls Mettray Penal Colony a "marvelous flower" in "blossoming France", and in his further works he continues to flower his characters with different flowers, hiding their black souls in symbols of purity and eternity. That was the way Genet achieved his primary goal that was the desire to purify the marginal world in the eyes of the reader by decorating the characters of his novels with the attributes of divinity, to describe it in the language of symbols, the meaning of which is clear to everyone.

The narrator tries to bring the killer of Harcamone to the rank of the saints. "Miracle of the Rose" is a song about his glory as his own God. During the novel the author prepares us to the miracle to come true, and in the end, in the episode of Harcamone's execution his heart is revealed as a rose after his death: "<...> rose monstrueuse de taille et de beauté. La Rose Mystique $<\ldots>$ " 37 . For the narrator “<... les roses, symbole d'amour et de mort”, which “<...> veut dire l'amour, l'amitié, la mort... et le silence!" 39 . In Christian symbolism the rose is an embodiment

${ }^{35}$ Genet J. Miracle de la rose // Oeuvres completes de Jean Genet / Jean Genet. - II. - Paris, Gallimard, 1952. P. 115.

${ }^{36}$ Ibid. P. 202.

${ }^{37}$ Ibid. P. 285.

${ }^{38}$ Ibid. P. 165.

${ }^{39}$ Ibid. P. 210. 
of the Grail identified with the Christ's heart (that is the origin of emblem of the Brothers of the Rosy Cross who regarded it as the embodiment of bodily and spiritual purity). As a symbol of rebirth, it emits a bright light after Harcamone's death, and everyone fades to see such a miracle. Rewarded for his holiness the criminal resurrects.

Harcamone's first appearance on a jail walk is described as follows: “<...> firent cette chaîne se transformer sous nos yeux à peine surpris, en une guirlande de roses blanches. La transformation commença au poignet gauche qu'elle entoura d'un bracelet de fleurs et continua le long de la chaîne, de maille en maille, jusqu'au poignet droit. HHarcamonee avançait toujours, insoucieux du prodige ${ }^{40}$. Garlands along with wreaths are the attributes of life, death and holiness; resurrection and immortality. With rose garlands, angels flew over the great martyr Dorothea which was condemned to death for refusing to renounce her faith. The white colour of the flower proclaims purity, virtue and love for God. In addition, the rose means heavenly reward for holiness. Harcamone, adorned with a crown of thorns from his hair, becomes a martyr for his faith: like Christ, he consciously went to the torment in the death chamber, and accepted his fate as inevitable. Turning his shackles into a rose garland proclaimed the mercy of God. The narrator is Harcamone's devoted follower and tries to follow him throughout. He cuts one rose from the chain and stores it until the killer's death (in Islam the follower received a rose from the master's hands, it symbolized the transfer of knowledge, because the flower is also a symbol of initiation). However, Harcamone did not give a rose to Jean by himself, so he was astonished by what happened, just like Jesus had been embarrassed by the touch of sick woman to his soutane, and this woman immediately healed, but took away some of his life power. This means that Harcamone has become the preceptor of the narrator against his own will, as well as his unseen mentor and God. Sometimes Harcamone appears as a rose meaning the Passion of Christ, that is his torments (the executioners which led him to execution, trample on flowers).

In contrast to "Our Lady of the Flowers", where roses are the attributes of many characters, in "Miracle of the Rose", they only decorate Harcamone and are only mentioned for him. In general, the colonists are simply compared to flowers, or, like Diaver, to "some plant". Only Bulken, Jean's executed lover, was "born in the land of the fern", and

${ }^{40}$ I Genet J. Miracle de la rose // Oeuvres completes de Jean Genet / Jean Genet. - II. - Paris, Gallimard, 1952. P. 19 
among ferns the narrator imagines him when writing "Doomed to Die" poem. Fern is a symbol of loneliness, gentleness and humility. Jean was humble to the fate that condemned him to loneliness after Bulken's death. During the character's wedding with Diver there is no veil, no orange blossom, no wreath. It predicts the fleetingness and artificiality of the alliance, and indeed Deaver sells Jean to another colonist. However, at his wedding with Bulken there are wreaths of orange blossom and a white satin dress with a tail, so the marriage is genuine.

Lily is one more pivotal symbol of the novel. It was the tattoos with lilies along with the "pansies" that prisoners decorated their bodies with. Lily is a symbol of sins atonement and the three virtues: faith, hope and mercy. It represents the aspect of the mercy of God. In addition, the lily played a significant role in the history of France. According to legend, the founder of the Frankish state, King Clovis I in the fifth century defeated the Germans on the banks of the Li River where lilies grew. The victors returned from the battlefield adorned with these flowers, and since then the flag and the emblem of France are embellished by three lilies representing the three virtues - compassion, justice and mercy. Genet referring to the Frankish nobility, writes: “<...> les seigneurs qui étaient d'abord des chefs militaires, disparurent sous l'écu qui était un signe, un symbole. L'élite qu'ils formaient fut tout à coup projetée dans une région sublime, contre un ciel abstrait ou elle s'écrivit. <...>. Quand le seigneur réapparut, humain fragile, derrière l'écu alourdi d'un symbole, il était chargé du sens obscur du symbole et dangereux comme le sont tous les habitants de la nuit, les habitants des rêves. <...>. Chacun est puissant et, quand celui qui l'a suscité se substitue au symbole, il profite de cette puissance mystérieuse" "41. Appealing to the inhabitants of hell who have turned "national symbolism into a swastika", he tries to give us back the primordial meaning of the lily symbol, which later was proclaimed by the Inquisition as an insult symbol, and witches and murderers were branded with it. The writer believed that tattoos sanctified criminals. And just like the symbols on the arms of the nobility, the tattoo "lifted them up on a pedestal", returned the ancient meaning as a symbol of purity, redemption, mercy. The lilies purified those branded by them.

Generally, tattoos are a sign of the prisoners' rank, so the more tattoos the thief has, the higher his hierarchical status is, the more respect he has. That's why Gaveille with his whole body covered in tattoos is "il se

${ }^{41}$ Genet J. Miracle de la rose // Oeuvres completes de Jean Genet / Jean Genet. II. Paris, Gallimard, 1952. P. 149. 
laissait mettre"42. When he allowed everyone to rape him, he lost his "flare of courage" in their eyes - "une fleur mâle",43 and became "on allait déflorer" ${ }^{\prime 4}$. The mention of tattoos in the form of lilies and pansies is also found in the novel "Funeral Ceremony", when the author recalls his fear of a crime "oozing from the abscesses of purple tattoo holes".

\section{The Importance of Floral Symbolism in Jean Genet's Novels "Funeral Rites" And "Querelle of Brest" And His Plays of The "Novelistic" Period}

In the "Funeral Rites" flowers are mostly ornamental: "Si j'ai voulu couvrir de fleurs le cercueil de Jean, c'est peut-être simplement dans un geste d'adoration, les fleurs restant ce qu'aux morts l'on peut offrir sans danger, et si l'habitude n'en existait déjà un poète pourrait inventer cette offrande. D'avoir prodigué les fleurs me repose un peu de mon chagrin” ${ }^{\text {"45 }}$. They accompany the funeral rite. The narrator prunes Jean D.'s coffin with rose and gladiolus petals (symbols of friendship, nobility and loyalty that rose on the site of unjustly killed warriors), oak branches (as a symbol of Christ, as a manifesting force in distress) and ivy (evergreen plant - the embodiment of immortality and eternal life, friendship, dependence, loyalty), and at the head he places a sage with laurel branches (courage, strength, thirst for victory; also laurel wreaths were awarded to a warrior in ancient times). It all illustrates the story of Jean D. as a patriot who had a violent heroic death and was reborn in the story thanks to his narrator lover. The injustice and futility of this death is signaled by the constant parallels between rotting remnants and beautiful roses " $<\ldots>$ se décomposant lentement, mêlant son odeur à celle des fleurs", "Jean pourrissait parmi les roses $\langle\ldots\rangle^{\prime 47}$ ) because the flowers continue to blossom and scent while the young lad lies in the grave, prematurely dead. The locals brought flowers to the place where Jean D. was killed to honor him. A little girl put white carnations in the iron tin, they are symbols of sadness and sorrow (the carnation according to Christian legend blossomed on the day Jesus was born; so it is very symbolic that this flower fell on Jean's tomb). An old woman put several flowers of marigold as a sign of purity and perfection. However the narrator is very indignant that all this exaltation

\footnotetext{
${ }^{42}$ Ibid. P. 152.

${ }^{43}$ Ibid. P. 152.

${ }^{44}$ Genet J. Miracle de la rose // Oeuvres completes de Jean Genet / Jean Genet. II. Paris, Gallimard,

${ }^{45}$ Genet J. Pompes Funèbres / Jean Genet. - Paris, Gallimard, 1953. - 307 p., 197.

${ }^{46}$ Ibid. P. 76.

${ }^{47}$ Ibid. P. 262.
} 1952. P. 152. 
after death is artificial, because if Jean D. had not died, no one would never mention his heroism, just like hundreds of boys standing for their ideals are forgotten ("Je les priverais d'un mort, et surtout d'un mort qui leur était cher à titre de mort" ${ }^{\text {48 }}$ ).

In this episode as in all others false feelings and disturbances are exposed by flowers. Thus when depicting the mischief of the funeral procession that accompanied Jean D.'s coffin, gladioluses suddenly flared about the hearse. The unnaturality and ridiculousness of belated worship is also revealed by the flowers immediately fading in cans $($ " $<\ldots>$ les gens vénèrent les morts en déposant au pied d'un arbre poussiéreux, dans des vieilles boîtes de conserves rouillées, des fleurs fanées" "49 "Elle se baissa et mit la botte de soucis dans une boîte rouillée qui contenait déjà des roses rouges fanées ${ }^{\text {"50 }}$ ). The coffin of dead child Jean D.’s child is decorated with artificial flowers of beads, but at the same time they are at least some kind of decoration of the funeral ceremony and display the insincerity of maternal sorrow (the mother during the mourning procession thinks of the mistress, of pleasure of dating her lovers, of corns on her feet, and not about her child). However after burial the mother remains on the grave with a daisy in her hands. This flower appeals to the deeper subconscious feelings of the maid. It is also a symbol of tears and blood, and laid on the tomb it is a symbol of embodiment of the innocence of the baby Christ, salvation and immortality. There are no flowers at all at the funeral of a monarch because such ceremonies are always extremely pompous and untrue in expressing emotions.

Floral symbolism is presented not that vividly in "Querelle of Brest" novel. Reminiscences to the symbolism of plants are manifested in the use of many words meaning "to sprout", "to blossom". For example, Querelle's image embodying the writer's innermost desires and hidden ideals, "blossoms in our souls", secret feelings that accompany the murder experience, "blossom” in Querelle’s mind ("Il laissait se développer en lui-même cet émoi qu'il connaissait si bien, qui <...> commanderait à son corps les gestes parfaits, serrés et sûrs du criminal" "51 " $<\ldots>$ à l'éclosion de ses meurtres" $" 52$ ect).

As in Genet's novels, in his plays "Deathwatch" and "Maids", floral symbolism plays an important role, it extends and deepens the meaning of the depicted events, appeals to archetypal thinking. Thus in the

\footnotetext{
${ }^{48}$ Genet J. Pompes Funèbres / Jean Genet. - Paris, Gallimard, 1953. - 307 p., 42.

${ }^{49}$ Ibid. P. 42.

${ }^{50}$ Ibid. P. 43.

${ }^{51}$ Genet J. Querelle de Brest / Jean Genet. - Paris, Gallimard, 1953. - 247 p., 52.

52 Ibid. P. 68.
} 
"Deathwatch" floristry is represented primarily by rose and lilac. Using the complex and meaningful symbolism of the rose in "Deathwatch" the author uses the Christian interpretation of the rose as the embodiment of martyrdom, rebirth, and eternal life. It grew from the drops of Christ's blood on Calvary ("MAURICE: C'est des têtes comme la mienne qu'on voudrait découper dans les journaux. <...>. Le sang coulerait. Et les larmes. <...>. Après je n'aurais plus qu'à me transformer en rose $<\ldots>$ " 53). And it is in this play that Genet first addresses to the interpretation of a rose as a symbol of caution and prudence. The character named Green Eyes did not want to be the killer and had wanted to be turned into a rose to deceive his fate.

The core symbol for "Deathwatch" is lilac, a flower that means the awakening of the first love feelings, beauty and rebirth. In the play lilac becomes a symbol of murder. With his help, Green-Eyes enticed the girl into his place ("YEUX-VERTS: Entre les dents j'avais une grappe de lilas. La fille me suivait. Elle était aimantée..." ${ }^{54}$ ). At the same time the lilac also disclosed him - thanks to the lilac flowers in the hair of the dead girl the police arrested Green-Eyes. ("YEUX-VERTS: Du lilas! Une toute petite grappe dans ses cheveux, et personne pour me prévenir" ${ }^{\text {") }}$ ). The lilac branch became a kind of symbol of the girl's death and the birth of the new Green-Eyes, marked his initiation. That's why, knowing that Lefranc was deeply influenced by the Green-Eyes story about "crime and lilac", and this could push him to crime, Maurice exclaims: "MAURICE: Elle te donne des forces? Elle remonte. Le lilas te remonte aux dents?"56. Thus the flower becomes a harbinger of crime, its sign.

In "The Maids", Genet uses more floral symbolism than in the previous play. Symbols of roses, gladioli, mimosas and lime trees, performing metaphorical and characteristic functions, give the theatrical action the status of a ritual, a sacred mystery. Claire and Solange decorate Madame's room with many flowers, unknowingly reproducing the funeral rite. The selected varieties of flowers indicate the intentions of the maids. We see roses and gladioli in the vases (the symbols of victory, strength of character, secrecy), as well as mimosa (embodiment of belief in the resurrection and forgiveness), carnations ("flowers of fire and struggle"). Flowers in the room seem to signal to Madame that something secret is going on here, that her Claire and Solange are ready to rebel against her.

\footnotetext{
${ }^{53}$ Genet J. Haute surveillance : (Nouvelle version) / Jean Genet. - Paris : Gallimard, 1993. - 111 p., 54.

${ }^{54}$ Ibid. P. 66.

${ }^{55}$ Ibid. P. 66.

${ }^{56}$ Ibid. - 111 p., 103.
} 
Madame feels something in her heart as she constantly asks her sisters to pick flowers from her room.

The use of flowers as symbols of the cycle of birth, life, death, rebirth, and continuation of life once again points to the transient nature of the very fact of death for eternal immortality. Claire and Solange regard Madam's as an obstacle to freedom and want to kill her to live on. They have no hatred for her, as evidenced by their intentions. Even when preparing for Madam's murder, the sisters try to reduce her suffering and use lime blossom with gardening as a tool of crime. The linden tree has long been a symbol of responsiveness and goodwill, albeit in parallel with the embodiment of the fight for equality.

\section{CONCLUSIONS}

The use of the whole spectrum of floral symbolism is one of the leading features of the poetry of Genet. Such a desire for floristry was formed in the writer's childhood whose youthful years were spent in the Mettray Penal Colony penitentiary, simply "immersed in flowers and greenery". The most important and therefore the most used by the author is the symbol of rose, which in the 16th century was tattooed on the shoulders of death row convicts. For Genet prisoners sentenced to death were Gods, so they had all the attributes of Christ and Notre-Dame. Flowers in his novels and plays are expressions of love and hate, signs of life and death, real and artificial things. The ambivalence of floral symbols used on holidays and at funerals is close to Genet's marginal mentality. However if we base on writer's perception of death as a festive occasion that completes the initiation rite, it is quite logical that criminals desire to capture the crime scenes and corpses by flowers. In general floral symbolism performs different functions in Genet's novels. First of all it is a characteristical function, as aiming to reveal the inner world of characters and rehabilitating them in the eyes of society rather than describing their lives, Genet draws on the ambiguity of floral symbolism in depicting the beauty of the killers. In addition such polarity in the meanings of floral symbols corresponds to the duality of the characters that combine masculine and feminine, chastity and holiness, virginity and immorality. Using symbols of specific flowers the narrator enhances the significance of certain events (metaphorical function) and adds fullness and completeness to the images described. Stressing the importance to symbols of flowers in Christianity and other religions we assume that was the way Genet tried to "sanctify" the crime, to give the appearance of the sacred mystery to the immoral actions of the characters. 


\section{REFERENCES}

1. Colonna V. L'Autofiction (Essai sur la fictionnalisation de soi en littérature), thèse de doctorat de l'E.H.E.S.S., sous la direction de G. Genette [Електронний ресурс]. Paris: Ecole des Hautes Etudes en Sciences Sociales, 1989. 368 р. Режим доступу: http://tel.ccsd.cnrs.fr/ documents/archives.

2. Fredette N. Artifice et parure: le style factice // Figures du baroque de Jean Genet / Nathalie Fredette. Montréal: XYZ Édition, 2001. P. 47-71.

3. Genet J. Haute surveillance: (Nouvelle version) / Jean Genet. Paris: Gallimard, 1993. 111 p.

4. Genet J. Miracle de la rose // Oeuvres completes de Jean Genet / Jean Genet. II. Paris, Gallimard, 1952. 223 p.

5. Genet J. Notre-Dame des Fleurs / Jean Genet. Lyon: BarbezatL'Arbalète, 1948. 383 p.

6. Genet J. Pompes Funèbres / Jean Genet. Paris, Gallimard, 1953. 307 p.

7. Genet J. Querelle de Brest / Jean Genet. Paris, Gallimard, 1953. 247 p.

8. Sartre J.-P. "Saint Genet, comedien et martyr" // Oeuvres completes de Jean Genet. т. I. Paris: Gallimard, 1952. 674 p.

9. Лотман Ю. М. Символ в системе культуры // Избранные статьи. В 3-х т. - Таллинн: Александра, 1992 1993. Т. 1.: «Статьи по семиотике и типологии культуры». 1992. С. 191-199.

10. Покальчук Ю. Дзеркальні лабіринти «святого» Жене // Покоївки: [П'єса] / Жан Жене; [пер. із фр. та післямова Ю. Покальчука]. Львів: Кальварія, 2002. С. 80-125.

\section{Information about the author:} Semenets O. S.,

$\mathrm{PhD}$ in Philological Sciences, Head of the Foreign Philology Department, Academic and Scientific Institute of Philology and Journalism,

V.I. Vernadskiy Taurida National University 33, John McCain str., Kyiv, 01042, Ukraine 